\title{
FORECASTING OF THE INFLUENCE OF FINANCIAL INSTITUTIONS LOAN PORTFOLIO CHANGE FOR THE ECONOMIC SECTORS OF THE COUNTRY
}

\author{
Daiva Jureviciene, Laura Pupelyte
}

\begin{abstract}
Purpose of the article is to predict the interrelationship between the change of financial institutions loan portfolio and activities of the main economic sectors in Lithuania. Coherence between financial intermediation and economic growth cause a great interest of economists during the late decade. Prevailed opinion that banking sector is the reflection of economic growth and expansion and that its role - to intermediate in the saving and investing needs, reallocating funds between economic activities, was replaced by sentiment that strong and stable banking sector could be not only the result of economic development, but also the cause of this growth. The purpose of the article is to accomplish forecast of the influence of financial institutions loan portfolio change to the main economic sectors in Lithuania for 2013-2017 period.

Methodology/methods Analysis of variation of loan portfolio according economic sectors shows the tendencies of financing of various activities in the past. Regression - correlation analysis helps to identify the influence of loan portfolio changes and their impact for GDP and employment in separate economic sectors. The forecasting of different economic sectors was made using extrapolation methods (smoothing, trend line) and econometric method (one dimensional regression).

Scientific aim: Economic situation in Lithuania forces to estimate decisions made by banking sector that influence not only individual countries but also the global economy. In this regard, there is a natural question of whether the process of underway stagnation should be judged as a timely economic development stage, or perhaps as the result of policies pursued by financial institutions? Prerequisites for the problem situation forces to overhaul loan portfolio managed by financial institutions, evaluate its change on the country's economy sectors, and to investigate these relationships forecasts.

Findings: There is a strong link between financial sector development and economic growth. The results showed that the volume of loans has a very close interdependence with the GDP. Data obtained for loan portfolio forecasting for 2013-2017 showed that the growth of loans can be seen in all sectors except construction. Employment should grow only in public and retail sectors.

Conclusions (limits, implications etc): The most relationship with GDP was established in retail and public sectors. Determining the correlation coefficients and regression equations between loans and employment the strongest relationship found in retail, industrial and construction sectors. The study encountered lack of data for 2012, since the information about the composition of the loan portfolio in different sectors since November 2011 is no longer provided to the Bank of Lithuania.
\end{abstract}

Keywords: financial institutions loan portfolio, economical sectors, macroeconomic indicators and economic growth

JEL Classification: E22, E, 24, E51 


\section{Introduction}

\section{VERSITA}

The function of each financial market is - efficient allocation of financial resources to all financial market participants. This task is performed by the financial intermediaries - banks and other non-bank financial institutions, facilitating mechanism for the allocation of money between the players with the surplus and deficient. The prevailing opinion is that the developed financial sector may not only be the result of an economically strong state, but on the contrary - can make impact on economic growth itself.

After Lithuania's accession to the European Union in 2004, the commercial banks in terms of loans have become simpler and the country's economy has taken its rapid economic growth. In particular, rapid and expanding growth was in construction and retail, lightweight and cheap money encouraged massive public consumption. Increased money supply causes price instability and eventually the price rise led to the inflation rate increase. Such general changes of economic processes continued until 2008, when the overheated economy did not survive and withstand the growing threat of a recession. From the end of 2008, loans in litas (Lithuanian currency ${ }^{1}$ ) gradually became more costly, tighter credit conditions, the consumption decline and the country began to emerge a general dissatisfaction with banks, government policy and the country's bureaucracy. All these effects caused a lot of discussions and formed an opinion that the majority of these results are due to the banking activities, and even more - on loan portfolio changes. Such situation forces to re estimate loan portfolio managed by financial institutions and evaluate the impact of its change on the country's economic sectors. Thus is important to clarify predictions of relations between changes of financial institutions loan portfolio and activities of main economic sectors.

Impact of loan portfolio change on Lithuanian macroeconomic processes mainly examined: Dudzeviciute 2006, Ramanauskas 2005; Lakstutiene 2008. However, analysis of different of economic activities, to help build an effective economic policy, has not yet been performed.

This article deals with the financial institutions loan portfolio and its influence on the country's key economic sectors in 2004-2012. A forecast for 2013-2017 year is performed. Systematized researches related to the influence of the financial sector in economic development. Empirical assessment of loan portfolio and the country's economic indicators (GDP, employment) trends is made. Using statistical models the dependence of the economy's sectors growth on the loan portfolio change is examined. A forecast of expected changes in the loan portfolio in 2013-2017 is presented and what impact it would have for GDP and employment volumes in main sectors.

Based on both, the empirical and theoretical researches examined in the literature as well as analysis done in this article on loan portfolio and the country's economic sector indicators relationship leads to the conclusion that there is a strong link between the financial sector development and economic growth. Accomplished regression-correlation analysis shows that the volume of loans has a very close interdependence with the GDP in retail and public sectors.

In determining the correlation coefficients and regression equations between loans and employment strongest relationship was found in retail, industrial and construction sectors. Loan portfolio forecasting for 2013-2017 showed the growth of loans in all sectors except construction. Regression prediction model composed ascertains that a volume of GDP is likely to grow as well in all sectors, except in the construction sector.

Employment should grow only in public and retail sectors, whereas in the agricultural sector there is an inverse relationship between the variables, and predicted loans in the industrial and construction sectors are not sufficient to increase the number of the employed. As the study encountered lack of data for 2012 in further studies would be more appropriate to analyze the change in the overall loan portfolio including more variables, or to use the data for several countries in order to compare the benefits of their decisions.

\section{The Influence of Financial Sector Fluctuation on Countries Economic Growth}

\footnotetext{
${ }^{1} 1$ euro equals 3.4528 litas.
} 


\section{$+1$ VERSITA}

Increasingly states that the financial sector makes an effective contribution to economic growth by increasing or limiting funding for the country, changing credit conditions. Lithuanian authors usually analyze or only the financial sector development (Garbaravicius, Kuodis 2002; Ramanauskas 2005b

; Kuodis 2008) or separately macro economic development of the country (Starkeviciute 2011; Aslund 2011). Financial sector contribution to economic development in Lithuania studied a little (Dudzeviciute 2006; Lakstutiene 2008; Balkevicius 2012), but in the foreign literature have been a number of studies analyzing financial reforms, to check and understand the existence of links between the real economy and financial sector development (Levine 2005; Beck, Demirgüc-Kunt, Laeve, Levine 2008; Kendall 2009; Zhang, Wang, Wang 2012 and others).

The first scientist, who started the search of the links between the financial sector and economic growth, was Schumpeter (1912). He notes that a well-functioning financial system promotes technological innovations, which lead to economic growth. Goldsmith (1969) accomplished the first innovative practical test using the figures of 35 countries. It was found a positive relationship between financial sector and economic indicators, but the reason why these relationships exist has not been determined. King, Levine (1993) conducted research in 77 countries, with 1960 - 1989 data. Calculating the regression analysis more variables were included, such as education, retail, and political stability. Levine, Zervos (1998) found that economic growth depends on the liquidity of the stock market and financial sector performance. In further investigations Levine, Loayza, Beck (2000) applied a more advanced econometric method GMM (generalized moments method) and examined data from 1960 to 1995 in 71 countries. The results also confirmed that there is a relationship between financial markets and the economy (in this case GDP) growth. Rousseau, Wachtel (2002) estimate the link between the financial sector and inflation.

Another part of researches were carried out by assessing only one selected country indicators. The difference between the neighbouring countries, and one individual national study would be that certain characteristics of the financial markets differ. Carried out studies by Jayaratne, Strahan (1996) in the U.S. have shown that improved quality of bank lending accelerated economic growth. Carried out studies by Dehejia, Lleras-Muney (2003) in the U.S. has confirmed that a well-functioning financial market has a positive effect on economic growth (improving the allocation of capital). Beck Levine, Levkov (2010) found strong links existing between the banking and investment, import, business development when examining data from 1979 to 1990 year. Kendall (2009) studied the Indian market and has proved positive correlation between the depths of the financial sector (measured by ratio of credit to GDP) with economic growth. Obtained results of the study of ten African countries financial development and economic growth (Akinlo, Egbetunde 2010) presented different hypotheses for different countries. Studies have shown that the development of the financial system promotes economic growth in Congo, Gabon, Nigeria, and Zambia, Kenya, Chad, South Africa, found a two-way relationship between financial development and economic growth. Complete, in variety of techniques carried out researches in China (Zhang, Wang, Wang 2012) has shown that financial development is positively related to economic growth.

Also important studies have been conducted examining the financial sector and the economic growth relations in industry and firm level. Rajan, Zingales (1998) found that industries that are more dependent on external financing have higher rates in countries with more developed financial markets. Wurgler (2000) used industry data to determine the dependence of financial development and economic growth through capital distribution channels. Kumar, Rajan, Zingales (1999) found that the average size of firms that depend on external finance is larger in countries with more developed financial system. Beck, Demirgüc-Kunt, Laeven, Levine (2008) studied indicators of 54 countries and found the impact of financial barriers to business growth. The results show that the most affected are small businesses. Thus, in countries with well-developed financial system industries with a higher share of small business is expanding rapidly. Both phenomena encourage similar reasons and conditions. Knowing one of these factors change with a high probability can be predicted the results of the second factor (Dudzeviciute 2006). 


\section{VERSITA}

\section{Retrospective Analysis of Lithuanian Financial Institutions Loan Portfolio}

The loan portfolio of banking system has changed significantly from Lithuania's accession to the European Union (Table 1). Customers' loans (non-financial corporations and households) amounted to 15.68 billion litas at the end 2004. The loan portfolio increased by $238.4 \%$ throughout the analyzed period and in the end of 2012 reached 53.06 billion litas. Constant loan growth in 2004-2008

was mainly affected by the emerging economic situation in the country, underpinned by strong domestic demand and concessional credits issued. Expectations related to Lithuania's membership in the EU, access to structural funds gave also a positive impact (The Bank of Lithuania, 2004). Especially a big jump in the credit market was in 2007, when the volume of loans increased by 17.09 billion (representing $45.85 \%$ change) litas. Prevailing economic crisis in Lithuania in second half of 2008 has led to an even worse outcome - credit growth in 2009 was negative and amounted to 6.43 percentage points, or nearly 4.2 billion litas. The situation remained similar in 2010 - loan portfolio even further decreased (7.3\%). During 2011 - 2012 m. loans slowed down, fall was only $3.42 \%$ in 2011 and respectively $3.98 \%$ in 2012 .

Table 1 The Changes of the loan portfolio to non-financial corporations and households

\begin{tabular}{|c|c|c|c|c|c|c|c|c|c|}
\hline & 2004 & 2005 & 2006 & 2007 & 2008 & 2009 & 2010 & 2011 & 2012 \\
\hline $\begin{array}{c}\text { Granted } \\
\text { credit } \\
\text { volumes, } \\
\text { billion } \\
\text { litas }\end{array}$ & 15.68 & 24.14 & 37.28 & 54.38 & 66.00 & 61.75 & 57.22 & 55.26 & 53.06 \\
\hline $\begin{array}{c}\text { Absolute } \\
\text { changes, } \\
\text { billion } \\
\text { litas }\end{array}$ & - & 8.45 & 13.14 & 17.09 & 11.62 & -4.24 & -4.53 & -1.95 & -2.19 \\
\hline $\begin{array}{c}\text { Percent } \\
\text { changes } \\
\text { (chain) } \\
\%\end{array}$ & - & 53.93 & 54.463 & 45.86 & 21.37 & -6.43 & -7.35 & -3.42 & -3.98 \\
\hline $\begin{array}{c}\text { Percent } \\
\text { change } \\
\text { (basic) \% }\end{array}$ & - & 53.93 & 137.76 & 246.80 & 320.92 & 293.85 & 264.90 & 252.44 & 238.42 \\
\hline
\end{tabular}

Source: The Bank of Lithuania (2004-2011)

Examining the Lithuanian financial institutions loan portfolio is important to distinguish what the shares falls to each economic activity. This allows determining which sectors of the economy have been largely funded and how this has affected them. According to Statistics Lithuania and the Bank of Lithuania classifications the following main sectors of the economy are distinguished: industry, retail, construction, public administration and agriculture. Financial intermediation sector indicators are not included in this study as they are directly related to the functioning of financial markets and dependence search is not meaningful. Since November, 2011 after change of Loan Risk Database handling credit institutions no longer provide information to Loan Risk Database about the type of economic activity for which the lend. Thus, the study used data from 2004 (when Lithuania joined the European Union) till 2011.

Carried out analysis of the loan portfolio changes and its distribution by economic sector shows that loans issued increased rapidly since 2004 to 2008 (Graph 1). 


\section{VERSITA}

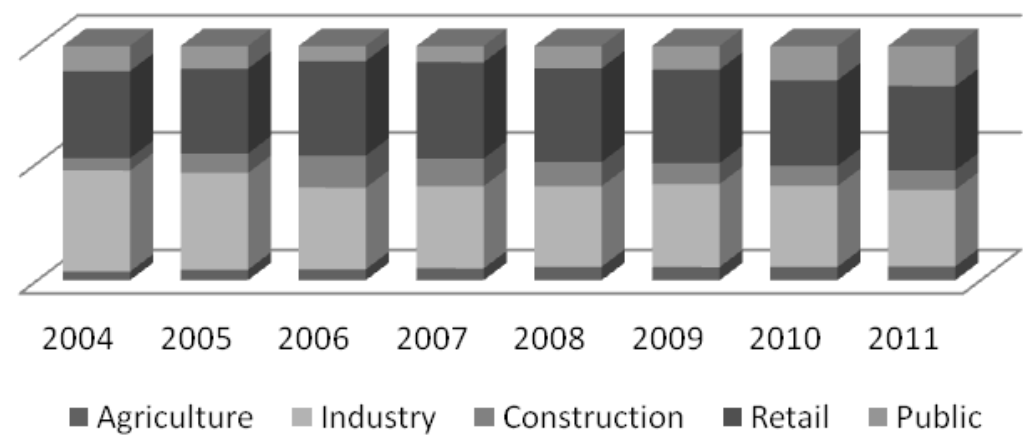

Source: The Bank of Lithuania (2004-2011)

\section{Graph 1 Loan Portfolio Distribution by Major Economic Sector, percent}

Banking predictions and expectations for the country's economy has been very positive, anticipate economic growth, stability. These findings are confirmed by almost 4 -fold increase in the volume of funding. However, the economy affected by the crisis in 2008 and made a significant impact on the loan portfolio either. In previous periods of actively funded economic activities industry, retail, real estate - has experienced extremely rapid decline in the loan portfolio. As shown in Graph 1, during 2008-2011 the share of retail sector loan portfolio decreased from $40 \%$ to $36 \%$ in the construction sector - from $10.3 \%$ to $8.2 \%$, and the industrial sector respectively, from $34.4 \%$ to $32.7 \%$. Due to decrease in economic activities until 2011 companies limited investment and their funding by debt financing.

\section{Dependencies between Loan Portfolio Change and Gross Domestic Product}

Graph 2 contains the evolution of the country's GDP volume indicators broken down into separate sectors. The changes of the curves suggest the growth of all activities GDP up to 2008 and only in the beginning of crisis the decline in one sector was greater, and other smaller.

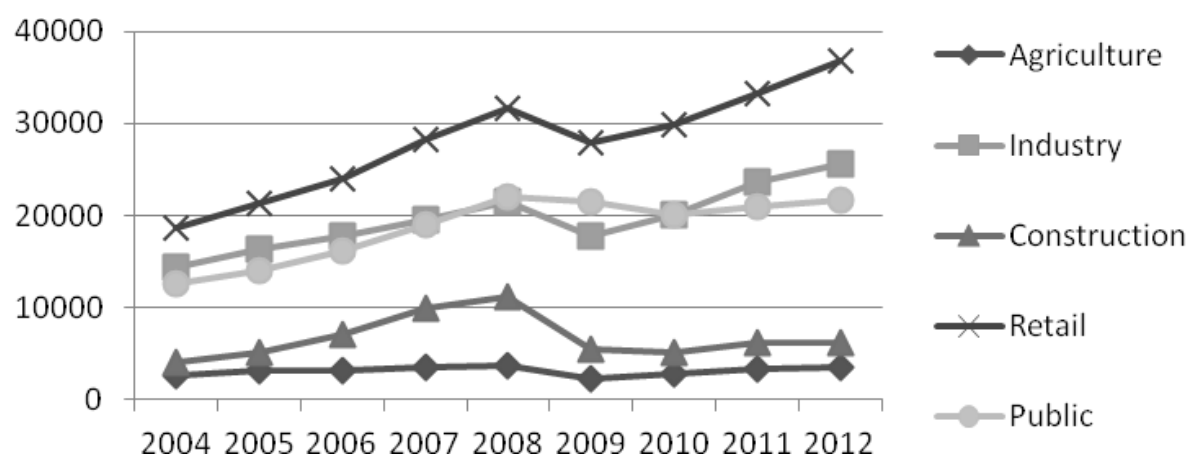

Source: Statistics Lithuania (2004-2012)

\section{Graph 2 Changes of GDP Volumes in the Main Economic Sectors, million litas}

Most of all GDP was created by the retail companies, industry took the second place. Public sector was in the third place, and unlike other sectors, GDP increases until the end of 2009. GDP rise in construction sector of was sharp, but did not exceed 10 billion litas level. GDP created in agricultural remained much the same - even not reached 5 billion litas level. Since 2010 the results again began to improve, the overall GDP growth was positive until 2012.

Changes in the loan portfolio and its impact on GDP changes determined from derived regression - correlation analysis. Relationship between the country's nominal GDP and credits 


\section{VERSITA}

provided by Lithuanian financial institutions in 2004-2011 is illustrated in Graph 3.

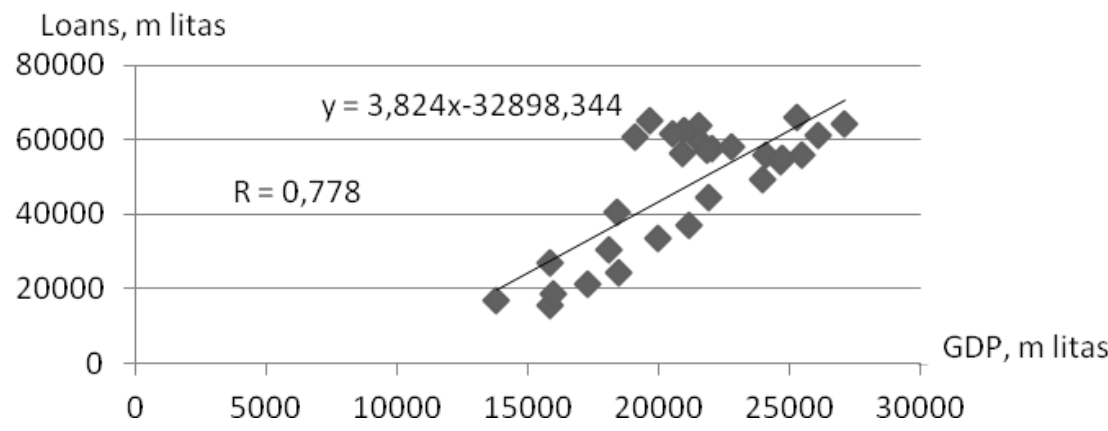

\section{Graph 3 Relationship of GDP and Financial Institutions Loans Granted}

GDP and loan portfolio interdependence is very close and direct - correlation index is 0,778 (Graph 3). It can be concluded that the more increased volume of credits granted, which in turn shifts consumer spending, more rapidly grow the country's nominal GDP.

To find out to which economic sector lending makes largest impact, the article deals with interdependence of each sector loan portfolio share with GDP. The correlation coefficients showed that the strongest stochastic relationship exists between the retail sector share in the loan portfolio and its GDP. The correlation coefficient is 0.721 , but the relationship is weaker in comparison to the total loan portfolio and the GDP. Regression equation shows that the retail sector share in GDP would increase 1 million litas, if the share of granted loans portfolio to the sector rise in average 1,461 billion litas $(\mathrm{Y}=1,224 \times 1-1463,016=1461,79)($ Graph 4$)$.

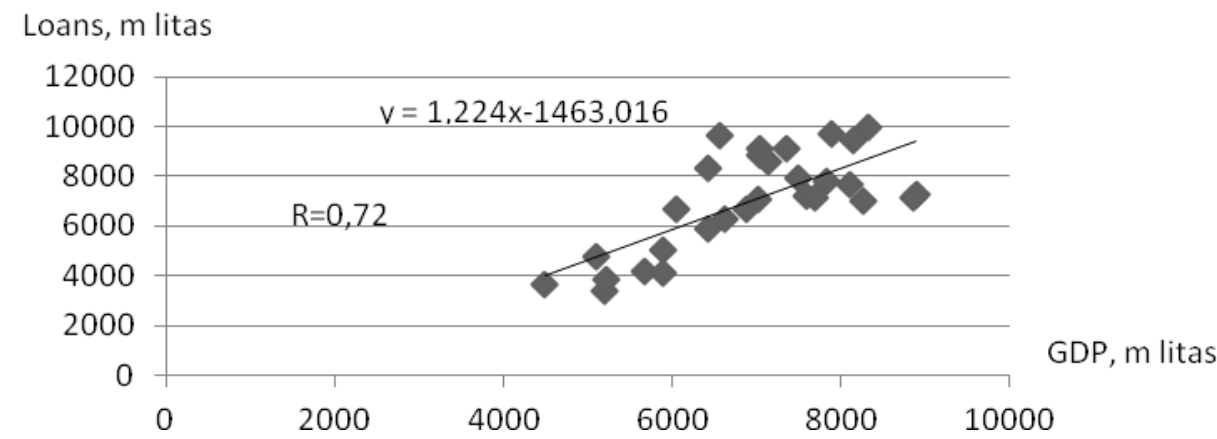

Graph 4 Relationship between GDP and Financial Institutions Loans Granted to Retail Sector

It is also a strong stochastic relationship (0.718) exists between the share of public sector loan portfolio and its GDP. Regression equation estimated by least square method showed that the share of public sector in GDP would increase if the granted loans portfolio to this sector rise (Graph 5). 
Loans, $\mathrm{m}$ litas

\section{VERSITA}

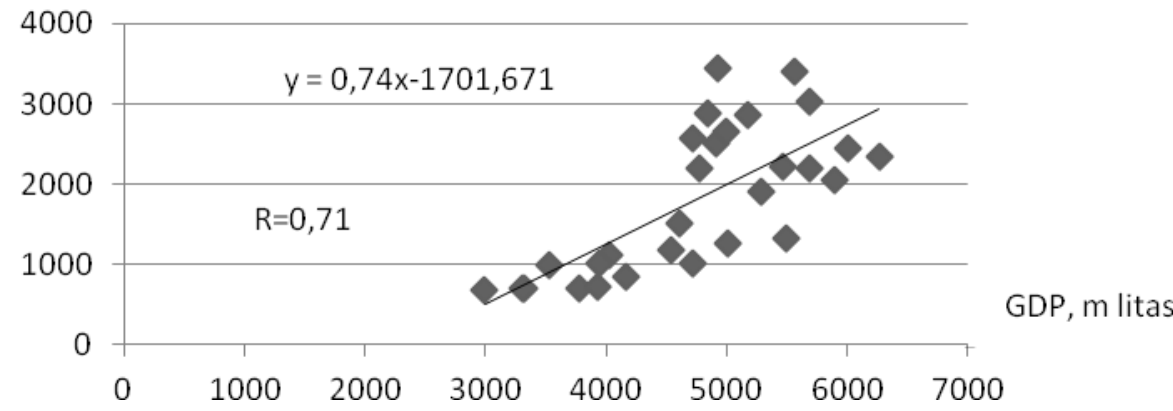

Graph 5 Relationship between GDP and Financial Institutions Loans Granted to Public Sector

Investigating the links between the construction sector share in the loan portfolio and its in GDP correlation coefficient obtained - 0.651. So it can be said that rapid rise in the loan portfolio for construction sector since 2004 to 2008 had a positive impact on GDP growth (Graph 6).

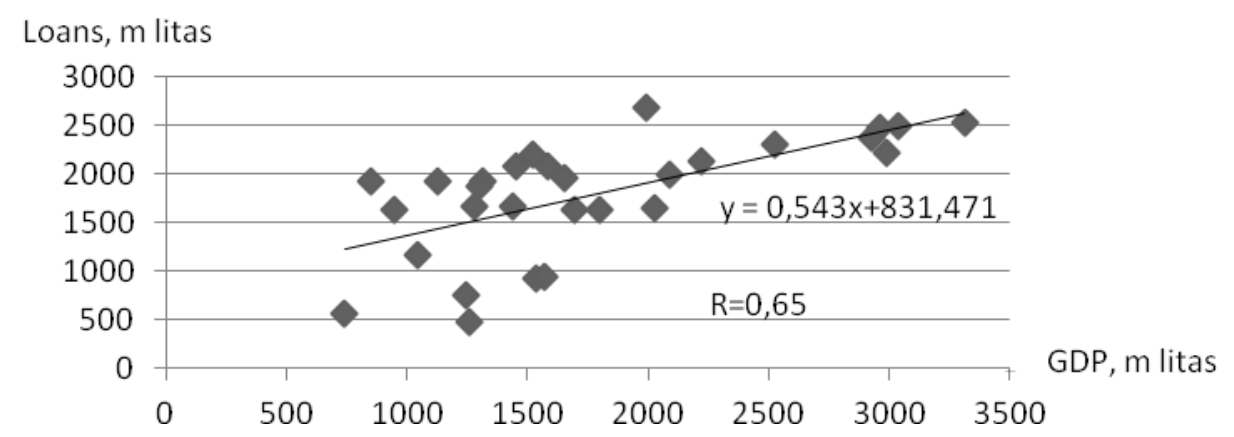

\section{Graph 6 Relationship of GDP and Financial Institutions Loans Granted to Construction Sector}

Interdependence between industry sector loan portfolio share and its share in GDP is also direct, but less strong than of others examined - 0,518. This could explain during the whole examined period the little change of GDP in this sector, though a significant increase in loan volume during the economic growth period. Companies need a considerable period of time until the funding received directly influences GDP increase; statistical set of points located around the regression line (Graph 7).

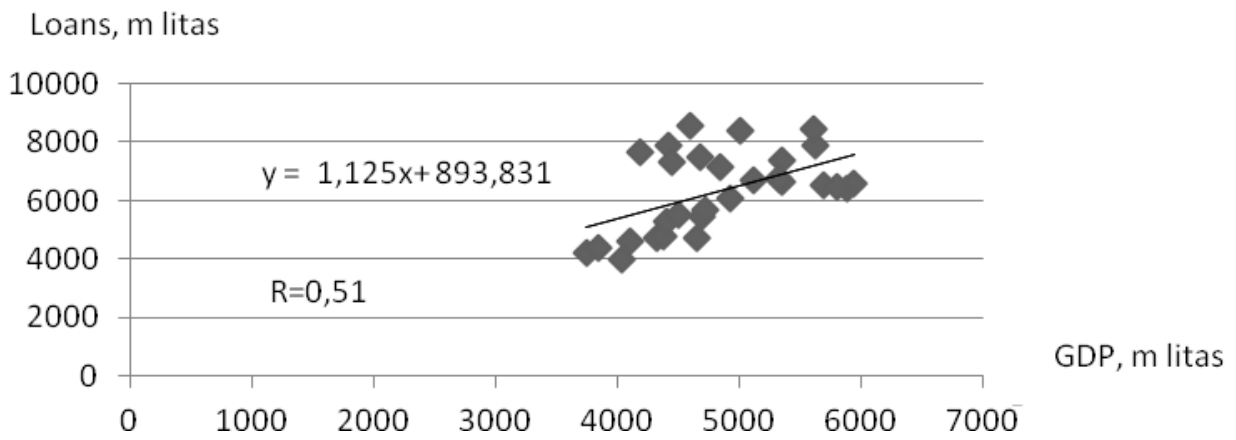

\section{Graph 7 Relationship of GDP and Financial Institutions Loans Granted to Industry Sector}

The lowest correlation coefficient (0.09) was between the agricultural share in the loan 


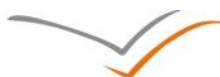 VERSITA}

portfolio and its share in GDP. Since Student criterion for this indicator was found less than the criterion value from the Student table $\left(\left|t_{s t}\right| \leq t^{\mathrm{kr}}\right)$,the finding of the existence of stochastic relation can not be done. Such an outcome could have been caused by the seasonal fluctuations of agricultural sector share in the GDP. Due to Lithuanian climate conditions turnover of farmers and at the same time created GDP is the highest in the third quarter of each year, while the amount of loans was not affected by the change in seasons.

Calculation conducted with the annual data showed that the correlation coefficient is still very low - 0.294. So we can not draw conclusions about the relationship between the agricultural share in the loan portfolio and its share in GDP. The reason for this was the EU structural support launched from 2007. One of the objectives of this project was to enable the diversification of economic activities in rural areas (The Ministry of Agriculture of the Republic of Lithuania 2008).

\section{Dependencies between Loan Portfolio Change and Employment}

Breakdown of employment by main country's economic sectors let to decide in which areas changes of employment were the largest. Number of employees during the analyzed period remained the largest in industrial sector (Graph 8).

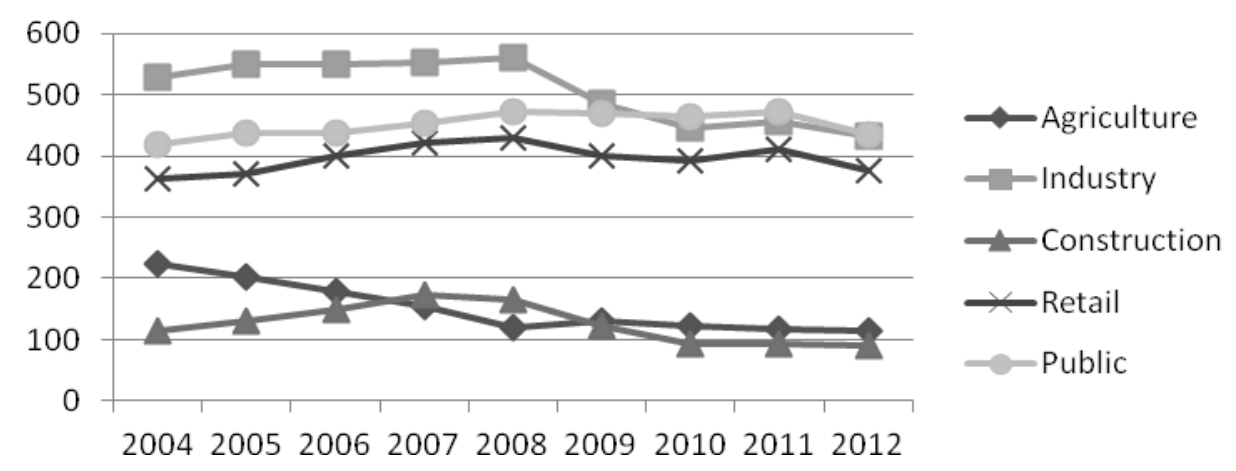

Source: Statistics Lithuania (2004-2012)

\section{Graph 8 Changes of Employment in Main Economic Sectors, thousands people}

Volume of employed in retail and public sectors since 2004 were similar, and from the beginning of the economic upturn since 2006 converged fully. Number of persons employed in the agricultural sector has tended to decline; only in 2009 was short-lived shift, where the number of employees amounted to 130,02 thousand people. This is a positive trend in developed countries, agriculture employs far fewer people. Rapid economic growth has increased the most number of the employed in the construction sector. Since 2004 volumes increased significantly and 2007 surpassed the number of persons employed in agriculture. However, the explosions of the real estate bubble in 2008 demand for construction workers again began to turn down and decline until 2012.

A review of the scope of employment may be concluded that the changes were significant. Further analysis seeks to clarify what impact could occur on employment within financial institutions loans. Examination of links received show a very low coefficient of determination and findings of the existence of stochastic relation can not be done. Dependence is mostly weakened by the fact that in 2008 the loans were still in the growth stage, and the decline in unemployment suddenly changed into a rather rapid rise in unemployment (Graph 9). This can be explained by the fact that banks' loan portfolio in 2008 grew out of inertia. While signs of the financial crisis have already been predicted, contracts and projects were not expired. One of the most evolved funded sectors was real estate which projects are under development even for several years. The banks' funding in 2008 was still positive in terms, while growth of the employment market was considerably more sensitive. Employers, perceiving the upcoming difficulties, began to optimize their business, reduce operating costs, number of employees. This was one of the main reasons why early as 2008 employment rates significantly 


\section{$\checkmark$

decreased. However, the calculations subdivided into two periods - from 2004 by 2007 and since 2008 by 2011 - get more accurate results. In the first period, the regression coefficient reached 0.91, and the second -0.61 .

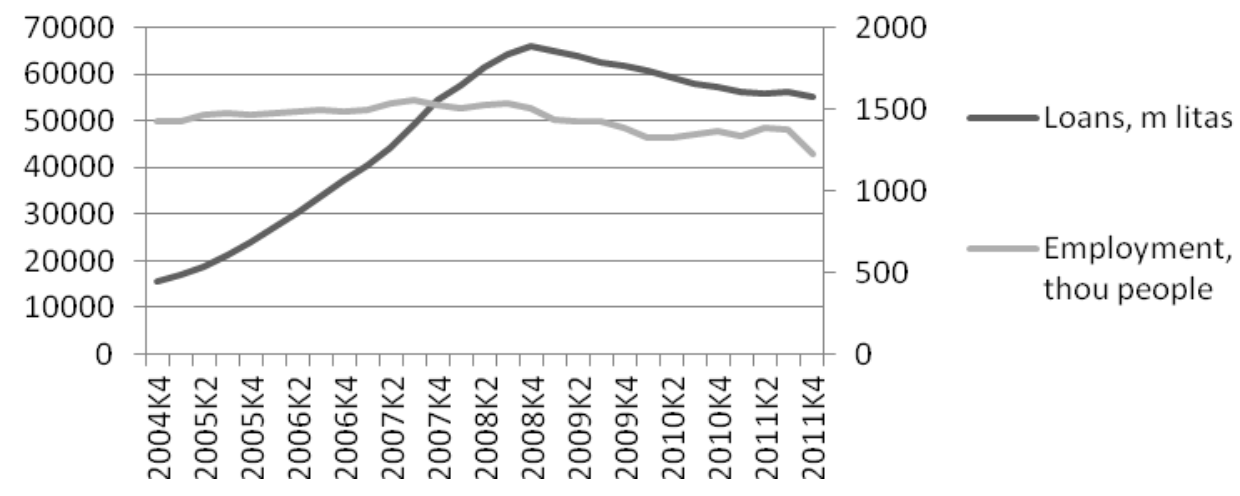

Source: Statistics Lithuania (2004-2012)

\section{Graph 9 Changes of Employment and Loan Portfolio during 2004-2012}

When trying to figure out for which of the economic sector lending makes the largest impact, the article examines interdependence of each sector loan portfolio share and the employment.

As mentioned (Graph 9) loan issuance in 2008 was still in the growth stage, and the employment suddenly changed in the rapidly growing unemployment. This situation is particularly reflected in the industrial and construction sectors, so finding a link between employment and share of loans in the analyzed period should be divided into two phases (from 2004 till 2007 and from 2007 till 2008).

The correlation coefficients showed that the stochastic relationship between the industrial sector share in the loan portfolio, and among share of the employed in the first period was 0.911, and the second 0,682 . Thus, among the variables there is a strong direct relationship and while other conditions being equal, it can be said that the loan portfolio changes influenced $91 \%$ and $68 \%$ increase of employment in the respective periods (Graph 10).

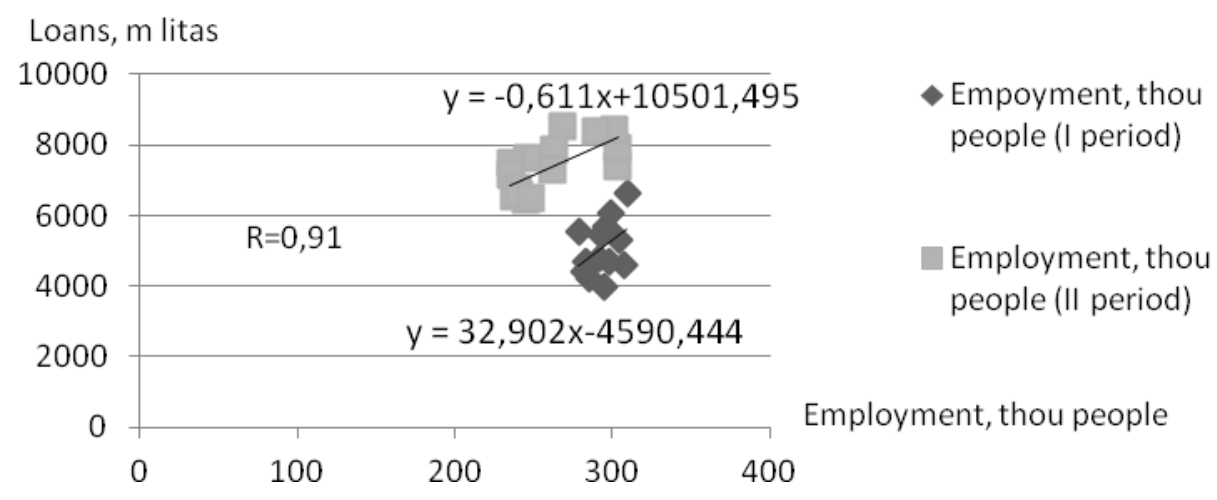

\section{Graph 10 Changes of Employment and Loan Portfolio in Industrial Sector}

Relationship of interdependence between the construction sector share in the loan portfolio and its share in the employment is direct and is also strong. In the first period it was 0.91 and 0.89 in the second. These results confirm that during boom progress in the construction sector received funding from the financial institutions let expanding operations, and at the same time creating new 


\section{$\checkmark$ VERSITA}

jobs. Estimated regression equation (Graph 11) by least squares method shows how a change in one unit of factorial variable (loan portfolio) influences the change of secondary variable (employment). According to available data and other conditions unchanged, in the second phase - from 2008 - due to 1 billion litas increase in commercial banks granted credit volume, 0,325 thousand people become employed.

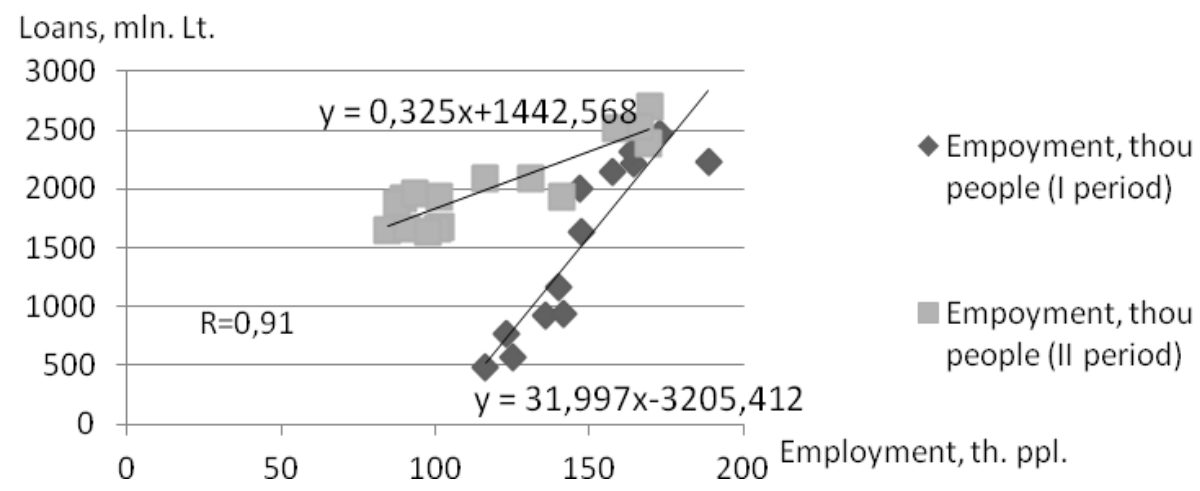

\section{Graph 11 Changes of Employment and Loan Portfolio in Construction Sector}

Analyzing the entire period from 2004 to 2011 the strongest stochastic relationship (-0.9) was found between the share in the loan portfolio and the share of the employed in agricultural sector. An inverse relationship between the variables is the surprising fact. This means that the number of persons employed in the agricultural sector would be reduced if the portfolio loans to this sector increase. That happens due to implementation the European Union structural assistance program. Farmers used received funding for modernization of equipment, ant this reduced the need for workers. In addition, to increase rural incomes, reduce the gap of standard of living between urban and rural areas alternative agricultural activities in the rural areas has been accelerated. Support and loans funding efforts have been made for rural residents who have increased employment and income from non-agricultural activities, thus employment in the agricultural sector has been steadily declining (The Ministry of Agriculture of the Republic of Lithuania 2012). Statistical set of points located around the regression line also confirms that there is an inverse relationship between the variables (Graph 12).

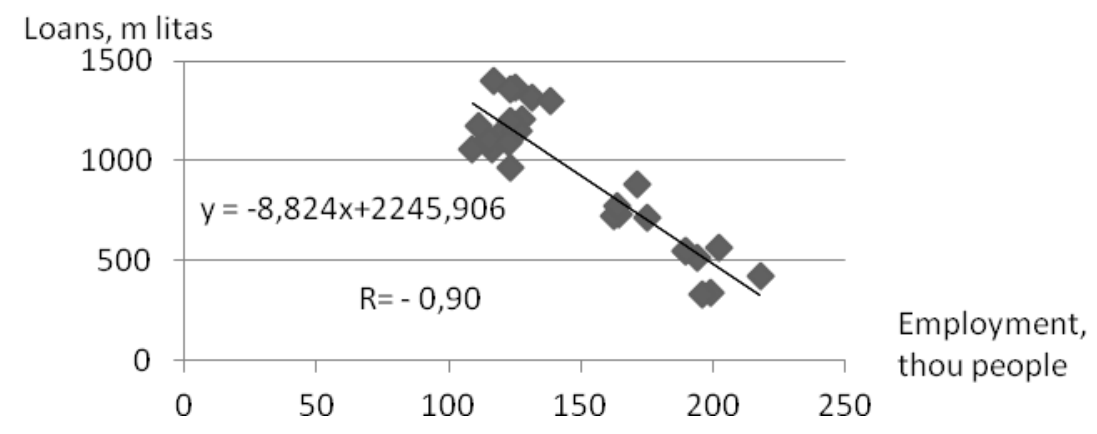

\section{Graph 12 Changes of Employment and Loan Portfolio in Agricultural Sector}

It is also a strong stochastic relationship (0.682) exists between the share of the loan portfolio and the share of the employed in retail sector. In this case dependence is direct and therefore issued loans had a positive effect on the retail sector employment. After paired regression analysis stochastic link and analytical expression is found (Graph 13). 


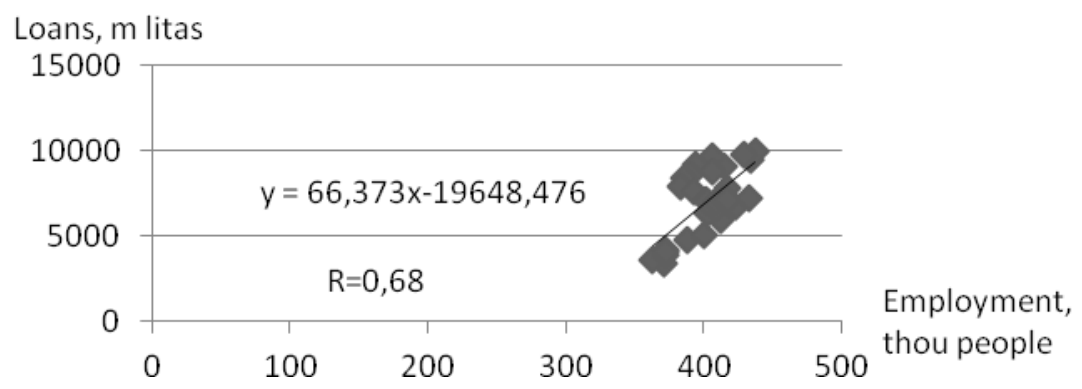

Graph 13 Changes of Employment and Loan Portfolio in Retail Sector

We can not infer the existence of a stochastic relationship between the share of the loan portfolio and the share of the employed in public sector, as found correlation coefficient is very low, and the indicator $\left|t_{s t}\right| \leq t^{\mathrm{kr}}$. Regression coefficient was calculated for the entire period from 2004 to 2011 and broken into two phases, but the results were the same. Data provided in Graph 14 show that employment changes in public sector during the period, changing regularly, but not much. Meanwhile, the public sector loans, since the end of 2009 has been steadily declining. It can be argued that financial institutions loans provided to public sector do not create more jobs in the sector. The funds received are used to deal with social problems, financing of education and training, and expanding job opportunities in all sectors.

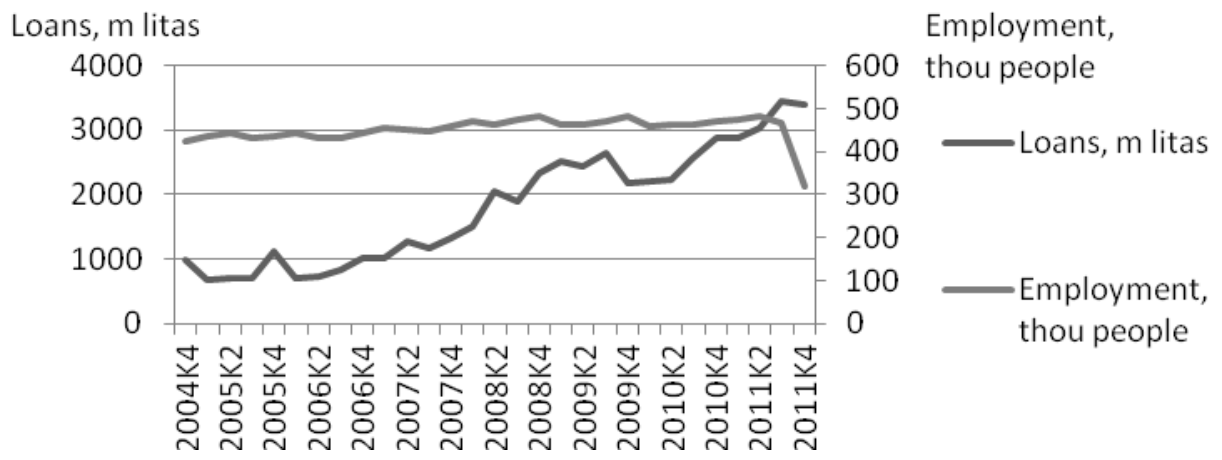

Source: Statistics Lithuania (2004-2011)

\section{Graph 14 Changes of Employment and Loan Portfolio in Public Sector}

Thus, exploring the links between the portfolio and employment can be said that in many sectors of the economy they are strong. During the 2004-2011 increasing number of loans granted increased employment. This is most experienced in retail, industrial and construction sectors. Only in the agriculture, hunting, forestry and fisheries sectors loans and employment dependency relationship was the reverse that was affected by the EU Structural Funds aims - economic diversification. Stochastic relationship between the share of loan portfolio and the share of the employed in the public sector was not found. This can be explained by the fact that the credits granted for public sector do not create additional jobs in the sector, as the funds are used to deal with social problems.

\section{Forecasting of Loan Portfolio Change and its Influence to Country Economic Sectors}

The loan portfolio change forecasting by moving average method showed that the growth of loans can be seen till the end of 2017 in all sectors except construction sector (Graph 15). From 1663.8 million litas loans issued at the end of 2011 for the construction sector they should decline to 1644.4 million litas at the end of 2017 (1.17\%). According to the forecast increase the most increase in the number of loans will be in public sector (5,2\% comparing to IV quarter of 2011). Credits issued to the agricultural sector should increase by $3.17 \%$, to retail sector by $0.6 \%$, and the industrial sector by $0.2 \%$ 
(comparing to IV quarter of 2011).

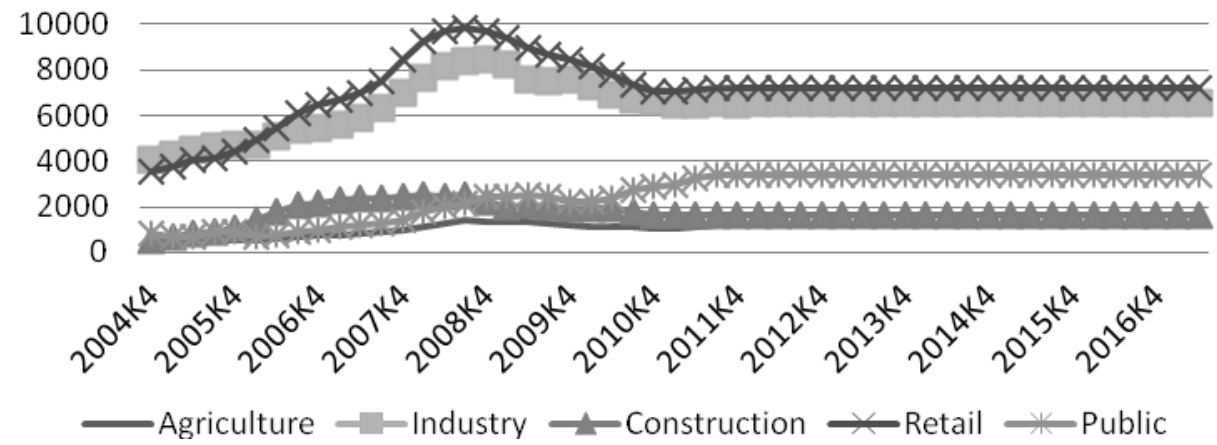

Graph 15 Loan Portfolio Forecast by Moving Average Method for 2013-2017 (million litas)

After examination of trends in the loan portfolio which will be in 2013-2017 and inserting the results obtained into the previously discovered regression equation the expected GDP and employment changes in the future are determined. The changes of GDP in public sector are indicated in Graph 16. The public sector loans change according forecast should be positive, the GDP in this sector compared to the end of 2011 increase $3.4 \%$ in 2017. Employment changes in public sector can not handle, as the loan portfolio and the employment stochastic relationship was not found and there is no regression equation.

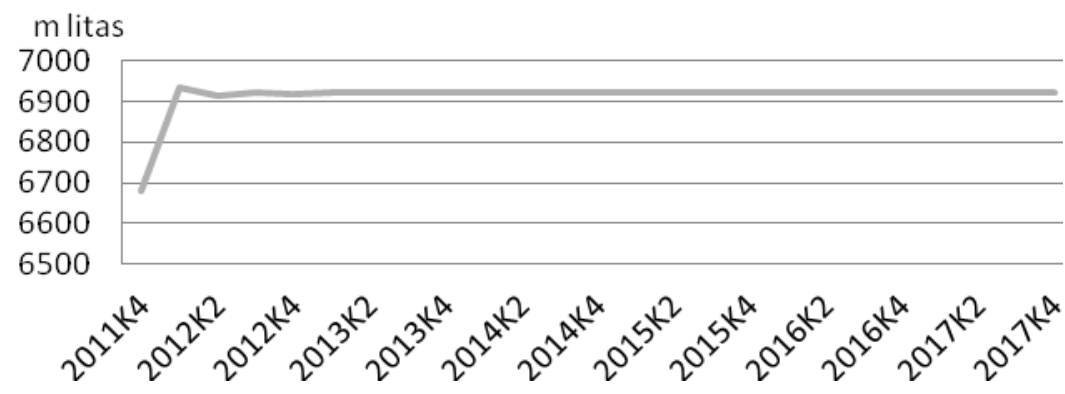

Graph 16 Loan Portfolio Forecast for Public Sector, 2013-2017 (million litas)

Through regression equation expected GDP and employment changes in the construction sector are calculated (Graph 17). It can be seen that both ratios tend to decrease, whereas due to the forecast the share of loan portfolio should be reduced in the construction sector. Compared to the 2011 fourth quarter data, GDP will decrease by $2.38 \%$ and employment by $2.11 \%$.

\section{Graph 17 Loan Portfolio Forecast for Construction Sector, 2013-2017}

The GDP and the number of people employed in retail sector according to the forecasts are expected to grow (Graph 18). If the prediction is realized and share of loan portfolio for this sector will grow by $0.6 \%$, GDP would grow $0.49 \%$, and the number of employees accordingly $0.16 \%$, that is about 1 thousand population. 


\section{Y VERSITA}

Graph 18 Loan Portfolio Forecast for Retail Sector, 2013-2017

Calculated forecasts for industry found that GDP would grow, but employment is still declining. Curve of GDP over five years to rise by $0.27 \%$ (Graph 19). Impact on employment reductions is similar - predicted to reduce the number of employees by $0.34 \%$ compared to the end of 2011.

\section{Graph 19 Loan Portfolio Forecast for Industry Sector, 2013-2017}

Different situation is seen after studying employment forecasts in the agricultural sector (Graph 20). While the loan portfolio in this sector according to the previously mentioned reasons should increase by $3.1 \%$, employment in this case decreases by $3.5 \%$. This is a normal phenomenon, as the stochastic relationship between the share of agricultural sector in the loan portfolio and the share of the employed is a reverse. Changes in the GDP in this sector can not be calculated, as stochastic relation was found in the loan portfolio to GDP, so the regression equation has not been concluded.

\section{Graph 20 Loan Portfolio Forecast for Agricultural Sector, 2013-2017 (thousand people)}

To sum up all forecasts, it can be said that significant changes should not be in the 2013-2017 period. Loan portfolio should decline only in the construction sector's share; funding obtained in other economic activities tend to the low growth. The basis for the negative outlook in the construction sector in 2011 was the continued decline in the loan portfolio in this industry. More accurate forecast would result after inclusion of data row and the results of 2012, but the information about the composition of the loan portfolio in different sectors since 2011 November no longer provided. Loan portfolio forecasting confirmed in all sectors except construction, GDP is expected to grow. Employment will grow only in public and retail sectors, whereas in the agricultural sector there is an inverse relationship between the variables and predicted loan growth in the industrial and construction sectors is not sufficient to increase the number of the employed.

\section{Conclusion}

Derived from the financial sector development and economic growth dependency theory analysis, it was concluded that there is a strong link between financial sector development and economic growth. Studies were carried out using both a national country and a number of neighbouring countries ratios, rates were also measured at the industry level. Various indicators has been used to estimate strength of links: investment, import, education, retail, political stability, inflation, bank loan quality, stock market liquidity, particularly a number of studies have been carried out in finding links between GDP and the number of credits issued.

In order to determine changes in the loan portfolio in different sectors of the economy, according to classifications of the Statistics Lithuania and the Bank of Lithuania the key sectors were identified: industry, retail, construction, public and agriculture. Constant loan growth in 2004-2008 was mainly affected by the emerging economic situation in the country, underpinned by strong domestic demand and concessional credits issued. It is estimated that the largest percentage of the loan has been granted to retail and industry activities. The minimum loan portfolio during the analyzed period had agricultural sector. Due to overheating economy in 2008 the growth rate began to slow down in 2009 and visible permanent loss of indicators was until 2012. The crisis most affected the construction and retail sectors, which in 2009 respectively decreased by $23.5 \%$ and $11.8 \%$.

GDP distribution volume in major sectors of the economy was similar to that of the loan portfolio. Up to 2008 GDP growth increased and only in the beginning of the crisis GDP decline in one sectors were larger and in others smaller. Mostly was exposed the construction sector, which fell by $51.95 \%$, and the industrial sector - decreased by $12.31 \%$. Another important indicator of the economy - 


\section{7 VERSITA}

employment rate increased until 2007 every year growing slightly less than $3 \%$. The reason was the growing economy, new jobs creation and continuing emigration. Since the beginning of 2008 the situation has changed - from the beginning of the economic downturn decreases consumption, corporate sales and at the same time labour demand. The biggest change in stagnation hit the construction sector, in which population employed in 2012 compared to the boom period (2008) fell $43.32 \%$, and the industrial sector $-19.84 \%$, respectively.

The conducted regresion-correlation analysis show the very close relation between volumes of granted loans and GDP. Change of credits granted during 2004-2011 causes similar change in nominal GDP. The most it manifests in retail and public sectors (the correlation coefficient was the strongest). The agricultural sector was affected by EU structural support, thus conclusion about the existence of the stochastic relation failed. Determining the correlation coefficients and regression equations between loans and employment in various sectors the strongest relationship found in retail, industrial and construction sectors. Between loans granted to the agricultural sector and employment there is an inverse relationship as EU structural assistance program effects employment. Farmers used the received funding for modernization of equipment, which reduced the need for workers. Also part of the population engaged in economic diversification and invested the funds received into other alternative businesses that increase employment in the service sector in rural regions. Stochastic relationship between the public sector share in the loan portfolio, and share of the population employed was not found. This happened because the credit granting to public sector does not create additional jobs in the area. The funds received are used to deal with social problems.

Following loan portfolio forecasting for 2013-2017 by extrapolation method, the lowest error found in the calculation by the moving average method, so these data are considered as the most significant. The data show that the growth of loans can be seen in all sectors except construction. According to the forecast loan portfolio should mainly expand in the public administration sector. Growth in agricultural, retail and industrial sectors will be negligible. Predictive regression model show that in all sectors except construction, GDP is likely to grow. Employment should grow only in public and retail sectors, whereas in the agricultural sector there is an inverse relationship between the variables, and the forecast results of loan increase in industrial and construction sector are not sufficient to increase the number of the employed.

\section{References}

Akinlo, A. E., Egbetunde, T. (2010). Financial Development and Economic Growth: The Experience of 10 SubSaharan African Countries. The Review of Finance and Banking, 2(1), 17-28.

Aslund A. (2011). 2008-2010 m. Rytų Europos finansų krizės pamokos [The Lessons of the Financial Crisis in Eastern Europe for 2008-2010]. Money Studies, 1, 78-85.

Balkevicius, A. (2012). Finansų sektoriaus raidos įtaka ūkio plètrai [Influence of the Financial Sector on Economic Development]. Mykolas Romeris University. Business systems and economics, 2(2) 82-94.

Beck, T., Demirgüc-Kunt, A., Laeven, L., Levine, R. (2008). Finance, Firm Size, and Growth. Journal of Money, Credit and Banking, 40(7), 1379-1405.

Beck, T., Levine, R., Levkov, A. (2010). Big Bad Banks: The Winners and Losers from Bank Deregulation in the United States. Journal of Finance, Forthcoming, 65(5), 1637-1667.

Dehejia, R., Lleras-Muney, A. (2003). Why Does Financial Development Matter? The United States from 1900 to 1940. National Bureau of Economic Research, Working Paper, 9551. 


\section{$\checkmark$ VERSITA}

Dudzeviciute, G. (2006). Lietuvos bankininkystès sektoriaus poveikis ekonomikos augimui [The Impact of Banking Sector on Economic Growth: Theoretical and Practical Aspects]. Business: Theory and Practice, 8(2), 128-135.

Garbaravicius, T., Kuodis, R. (2002). Lietuvos finansų sektoriaus struktūra ir funkcionavimas [The Structure and the Functioning of the Financial Sector in Lithuania]. Monetary Studies, $1,18-47$.

Goldsmith, R.W. (1969). Financial Structure and Development, New haven, U.S., Yale University Press, 36.

Jayaratne, J., Strahan, P.E. (1996). The Finance-Growth Nexus: Evidence from Bank Branch Deregulation. Quarterly Journal of Economics, 111(3), 639-670.

Kendall, J. (2009). Local Financial Development and Growth. The World Bank, 4838, 38.

King, R.G., Levine, R. (1993) Finance and Growth: Schumpeter Might Be Right. Quarterly Journal of Economics, 108(3), 717-738.

Kuodis, R. (2008). Lietuvos ekonomikos transformacija 1990-2008 metais: etapai ir pagrindinès ekonominès politikos klaidos [Lithuanian Economic Transformation of the year 19902008: stages and Main Economic Policy Mistakes]. Monetary Studies, 2, 97-105.

Kumar, K. B., Rajan, R.G., Zingales, L. (1999).What Determines Firm Size? National Bureau of Economic Research, Working Paper, 7208.

Lakstutiene, A. (2008). Bankų sektoriaus rodiklių ir bendrojo vidaus produkto priklausomybès tendenciju vertinimas [Correlation of the Indicators of the Financial System and Gross Domestic Product in European Union Countries]. Engineering Economics, 3 (58), 7-18.

Levine, R., Zervos, S. (1998). Stock Markets, Banks, and Economic Growth. American Economic Review, 88 (3).537-558.

Levine, R. (2005).Finance and Growth: Theory and Evidence. Handbook of Economic Growth, Amsterdam, Netherlands, Elsevier, Chapter, 12, 1(1), 865-934.

Levine R., Loayza, N., Beck, T. (2000). Financial Intermediation and Growth: Causality and Causes. Journal of Monetary Economic, 46(1), 31-77.

Rajan, R. G., Zingales, L. (1998). Financial Dependence and Growth. American Economic Review, $88(3), 559-586$.

Ramanauskas, T. (2005). Bankų kredito didèjimas makroekonominiu požiūriu [Assessment of bank credit growth from macroeconomic perspective]. Monetary Studies, 3, 78-97.

Rousseau, P.L., Wachtel, P. (2002). Equity Markets and Growth: Cross-country Evidence on Timing and Outcomes, 1980-1995. Journal of Banking \& F2inance, 24(12), 1933-1957.

Schumpeter, J.A. (1912). Theorie der wirtschaftlichen Entwicklung. Duncker \& Humblot, 176-198.

Starkeviciute, M. (2011). Makroekonominis nesubalansuotumas, priežastys ir pasaulinè valdysena [Macroeconomic imbalances: determinants and global governance]. Monetary Studies, 1, 64-77. 


\section{VERSITA}

Statistics Lithuania (2004-2012). Employment Rate. [Online] [Cited 2013-01-10] Available from Internet: <http://db1.stat.gov.lt/statbank/default.asp?w=1280>

The Bank of Lithuania (2004-2011). Loan Portfolio to Non-financial Corporations and Households. [Online] [Cited 2012-12-08] Available from Internet : http://www.lb.lt/stat_pub/statbrowser.aspx?group=7274\&lang=lt

The Bank of Lithuania (2004). Lithuanian Economy Review. Vilnius. [Online] [Cited 2013-02-08] Available from Internet: < http://www.lb.lt/metu ataskaita 2004>

The Ministry of Agriculture of the Republic of Lithuania. (2012). An Overview of the Implementation of the Lithuanian Rural Development Programme for 2007-2013. [Online] [Cited 201301-17] Available from Internet: 〈http://www.zum.lt/index.php?-290116043>

The Ministry of Agriculture of the Republic of Lithuania. (2008). Lithuanian Agriculture Review, 162.

Wurgler, J. (2000). Financial Markets and the Allocation of Capital. Journal of Financial Economics, 58(1-2), 187-214.

Zhang, J., Wang, L., Wang, S. (2012). Financial Development and Economic Growth: Evidence from China. Forthcoming on Journal of Comparative Economics, 40 (3), 393-412.

\section{Authors' contacts}

Prof. dr. Daiva Jureviciene, Laura Pupelyte; Mykolas Romeris University, Faculty of Economics and Finance management, Department of Banking and Investments; Ateities str. 20, LT-08303 Vilnius, Lithuania; +370 5271 4550; E-mail:daiva.jureviciene@mruni.eu; laura.pupelyte@ yahoo.com 